УДК 664.642.1, 664.66.019

\title{
Use of a probiotic yeast strain in technology of bread from wheat flour*
}

\author{
$P h$. $D$. E. V. SOBOLEVA ${ }^{1}, P h . D$. E. S. SERGACHEVA ${ }^{2}$ \\ 'elenavsoboleva@mail.ru, ${ }^{2}$ essergacheva@mail.ru \\ ITMO University, Russia 191002, St. Petersburg, Lomonosova str., 9 \\ Ph. D. G. V. TERNOVSKOY \\ gregory@ternovskoy.com \\ St.-Petersburg branch State Research Institute of a Baking Industry \\ Russia, 196608, St.-Petersburg, Pushkin, shosse Podbelskogo, 7
}

For the modern bakery is interesting to study yeast strains with good biotechnological properties and simultaneously antagonistic activity against pathogens of microbial spoilage of bread. The purpose of research - to study the effect of the probiotic strain of S. cerevisiae RCAM 01730 on the technological parameters of preparation of bread from wheat flour on the quality indicators of finished products and the suppression of rope in bread. Yeast antagonistic activity against spore-forming bacteria were determined by diffusion into agar. Immediate and total gas evolution in dough was evaluated using automatic risograph (USA). In order to detect signs of disease of rope in bread used method of placement the products in provoking conditions. The antagonistic activity of the strain of yeast $S$. cerevisiae RCAM 01730 with respect to the bacteria of the genus Bacillus was determined. The results of the research of the possibility of using a strain of Saccharomyces cerevisiae RCAM 01730 in wheat bread technology with sponge dough, straight dough, rapid dough methods were represented. It is shown that the use of a strain of S. cerevisiae RCAM 01730 instead of $02150 S$. cerevisiae RCAM accelerating gas formation in the dough, intensifies the maturation process of the dough. The study found that a strain of the yeast S. cerevisiae RCAM 01730 has a bacteriostatic effect on the pathogens of potato disease of bread. In contrast to existing labor-intensive and time-consuming biological methods of combating microbial spoilage of bread, the use of the yeast S. cerevisiae RCAM 01730 can be an effective way to increase microbiological resistance without any additional costs.

Keywords: bakers' yeasts, Saccharomyces cerevisiae, rope in bread, antagonistic activity, gas generation.

Информация о статье

Поступила в редакцию 23.03.2016, принята к печати 24.10.2016

doi: 10.21047/1606-4313-2016-15-4-11-15

Ссылка для цитирования

Soboleva E. V., Sergacheva E. S., Ternovskoy G. V. Use of a probiotic yeast strain in technology of bread from wheat flour // Вестник Международной академии холода. 2016. № 4. С. 11-15.

\section{Использование пробиотического штамма дрожжей в технологии хлеба из пшеничной муки}

\author{
Канд. техн. наук Е. В. СОБОЛЕВА ${ }^{1}$, канд. техн. наук Е. С. СЕРГАЧЕВА ${ }^{2}$ \\ 1elenavsoboleva@mail.ru, ${ }^{2}$ essergacheva@mail.ru \\ Университет ИТМО, 191002, Санкт-Петербург, ул. Ломоносова, 9 \\ Канд. техн. наук Г. В. ТЕРНОВСКОЙ \\ gregory@ternovskoy.com \\ Государственный научно-исследовательский институт хлебопекарной промышленности \\ (СПб филиал ГОСНИИХП) \\ 196608, Санкт-Петербург, г. Пушкин, и. Подбельского, 7
}

\begin{abstract}
Для современного хлебопечения представляет интерес изучение итаммов дрожжей, обладающцих хорочими биотехнологическими свойствами и одновременно антагонистической активностью по отночению к возбудителям микробиологической порчи хлеба. Цель исследования - изучить влияние пробиотического штамма $S$. cеrevisiae RCAM 01730 на технологические параметры приготовления хлеба из пиеничной муки, на показатели качества готовых изделий и на подавление картофельной болезни хлеба. Антагонистическую активность дрожжей по отночению к спорообразующим бактериям определяли методом диффузии в агар. Мгновенное и общее газовыделение в тесте оценивали с помощью автоматического ризографа (США). Для выявления признаков заболевания хлеба картофельной болезнью использовался метод закладки изделий в провоцирующцие условия. Установлена антагонистическая активность штамма дрожжжей S. сегеvіsiae RCAM 01730 отношению к бакте-
\end{abstract}

This work was partially financially supported by the government of the Russian Federation, Grant 074-U01. 
риям рода Васіllus. Представлены результаты исследований возможности использования итамма Sассһаготусеs cerevisiae RCAM 01730 в технологии пиеничного хлеба опарным, безопарным, ускоренным способами. Показано, что использование штамма S. сегеvisiae RCAM 01730 взамен S. сетеvisiae RCAM 02150 ускоряет газообразование в тесте, интенсифицирует процесс созревания теста. В ходе исследования установлено, что итамм дрожжей S. сегеvisiae RCAM 01730 оказывает бактериостатическое воздействие на возбудителей картофельной болезни хлеба. В отличие от существующих трудоемких и длительных биологическихметодов борьбы смикробной порчей хлеба, применение дрожжей S. сегеvіsiae RCAM 01730 может служить эффективным способом увеличения микробиологической стойкости, не требующим дополнительных затрат.

Ключевые слова: дрожжи, Saccharomyces cerevisiae, картофельная болезнь, антагонистическая активность, газообразование.

\section{Introduction}

Microorganisms play a great role in breadmaking. Eth$\mathrm{yl}$ alcohol and lactic acid fermentation, of which the main causes are Saccharomyces cerevisice yeasts and lactic-acid bacteria Lactobacillus, both take place in wheat flour dough. However, besides fermentating microorganisms spore-forming bacteria of the genus Bacillus such as B. subtilis, B. pumilus, $B$. licheniformis can develop in prefermented and final products. These microorganisms can cause rope in bread.

The main infection sources during bread production are flour, bran and grain [1, 2]. Violation of processing procedures and poor sanitary conditions can be the cause of the finild product disease. The vegetative cells of Bacillus bacteria die during baking in the oven, but their spores are heat resistant and can germinate during bread storage under favorable conditions [3].

At the first stage of spoilage, the bread loses its native flavor and then specific sweet odor appears similar to that of overripe melon or valerian $[4,5,6]$. During spoilage, the odor intensifies and takes on a putrefactive character. The crumb becomes sticky; when the loaf is torn one can see slimy stretchy strings. Sometimes these thin silvery slimy web like strings stretch up to $50 \mathrm{~cm}$. Hence the other name of this disease, the rope. In German such phenomenon is called «Fadenziehen des Brotes», in English, «Rope in bread», in Russian, «Potato disease». Crumb colour changes, blotches of yellow, brown and muddy pink appear. As the disease enters its final stage, bread turns into a dark slimy mass with a coarse odor and strong off-taste. The pores collapse, small holes and then larger ruptures appear in the crumb $[4,7,8,9]$.

Bacterial cells have active amylolytic and proteolytic enzymes. The proteins are broken down and amides, amines, amino acids and peptides appear. Starch is hydrolyzed into dextrin and mono- and disaccharides. The former contribute to bread crumb stickiness. Substances with a specific acrid odor are formed due to interaction of mono- and disaccharides with amines and amides. The amount of aldehydes and other compounds rises sharply which contributes to the rotten smell of the diseased bread [5,6]. Consumption of bakery products affected by rope can lead to poisoning by metabolites accumulated in them such as toxins and degradation products.

The main factors that inhibit the development of rope in bread and corresponding pathogens are high acidity, low humidity, increased content of sugar and fat in the product (15-20\% of the total weight of flour), the antibiotic activity of the medium. In this regard, bakeries use different methods, devices and techniques to fight rope in bread at all stages of manufacturing. There exist various methods for preventing the development of microbial spoilage of bakery products, chemical, physical and biological.

The most effective methods of rope control are biological methods, such that involve liquid yeast, sourdough and starter cultures. In recent years, there is significant demand for research of yeast strains capability to fight microbial spoilage of food substances of microbial origin [10]. Microorganisms of starter cultures used in baking are able to synthesize substances inhibiting exogenous microflora development in final products. The antagonistic activity of these microorganisms is due to accumulation of their metabolic products in semi products. The main batch of active metabolites is built up by lactic acid bacteria, which produce an array of natural antibacterial substances, including organic acids, carbon dioxide, hydrogen peroxide, diacetyl, ethanol, bacteriocins, reuterin, reutericyclin [10-14]. As to the yeast, their antagonistic role is not normally considered. However, in 1909 F. Hayduck published data on yeast proteins (killer factors) being toxic to other strains [15].

Antagonistic activity of yeast is caused by competition for nutrients, medium $\mathrm{pH}$ changing due to the ion equilibrium shift or formation of organic acids, production of large quantities of ethanol, release of antibacterial and antimicrobial substances, such as killer toxins - mycocins $[16,17]$. Mycocins are extracellular proteins, mainly glycoproteins, that inhibit normal cell membrane functioning (integrity, osmotic permeability) in yeasts that have receptors with corresponding sensitivity [16]. Mycocin activity is mainly targeted at yeast cells genetically closely related to the producer strain, serving as a protective factor.

The yeast $S$. cerevisice synthesize several types of killer factors, some of which attach to $\beta$-1,3-glucan chains, opening channels in the cell membrane of sensitive strains, and others attach to mannoproteins of the cell wall and inhibit DNA synthesis [18].

Mycocin production occurs not only in Saccharomyces yeasts but also in Candida, Cryptococcus, Debaryomyces, Kluyveromyces, Pichia, Torulopsis, Williopsis and Zygosaccharomyces [16, 17]. However, not much research was focused on the effect of killer factors on bacterial microflora.

It is well known, that the development of spoilage microorganisms has a direct impact on final product quality. Therefore adding antagonistic yeast starter cultures is bound to enhance product safety by inhibiting pathogenic microorganisms growth during fermentation and final product sensory qualities and shelf life by inhibiting spoilage flora development $[4-7,19,20]$. 
Saccharomyces cerevisiae yeasts are the principal microorganisms in bread production, and as such, they show promise as an innate antagonist to bacteria Bacillus spp that cause rope in bread.

\section{Materials and methods}

Yeast strains Saccharomyces cerevisiae RCAM 02150 and S. cerevisiae RCAM 01730, bacteria strains Bacillus subtilis $\mathrm{KM}$ and B. licheniformis 1, dough, wheat bread.

Antagonistic activity of yeast in relation to spore-forming bacteria was estimated by the method of diffusion into agar [20].

Bread production and storage tests. Yeast strains Saccharomyces cerevisiae RCAM 02150 and S. cerevisiae RCAM 01730 used in the experiment were grown in pilot plant conditions subject to all parameters and stages applied in pressed bakers' yeasts production on the industrial scale.

The bread doughs were obtained by kneading $1,000 \mathrm{~g}$ of wheat flour (labeled «premium» according to the Russian classification) and $560 \mathrm{~g}$ of tap water in a mixer (Kitchen Aid 5K PM5 Professional, St. Joseph, Mich.) for 5 mins at room temperature. Yeast inoculum added at this stage was such that resulted in about $1.0 \times 10^{9} \mathrm{CFU} \mathrm{g}^{-1}(1 \%), 2.5 \times 10^{9} \mathrm{CFU} \mathrm{g}^{-1}(2.5 \%)$, $4.0 \times 10^{9} \mathrm{CFU} \mathrm{g}^{-1}(4.0 \%)$ viable yeast cells in the resulting doughs. After mixing, the doughs were shaped into roughly $400 \mathrm{~g}$ loaves, placed in aluminum pans, and leavened at $35^{\circ} \mathrm{C}$ until the volume was twice the initial volume. The leavened doughs were baked in an oven at $210^{\circ} \mathrm{C}$ for $25 \mathrm{~min}$. After cooling, the samples were stored at $37^{\circ} \mathrm{C}, 90 \%$ humidity (provocative conditions). In 24 hours, the loaves were examined externally for the presence of the typical sweet fruity odor, which characterizes the first stage of rope disease. The breads that gave off an intense smell were cut into halves and their crumb was inspected.

The volume of gas produced by different strains during dough fermentation was measured by rizograph test fermentation (National Manufacturing). Dough made as described above was rolled into balls and left to ferment for a maximum of $240 \mathrm{~min}$ at $30^{\circ} \mathrm{C}$ in the rizograph test chamber. Gas volume was measured continuously at $1 \mathrm{~min}$ intervals [21].

\section{Results and discussion}

Strain S. cerevisiae RCAM 01730 was selected through the screening of yeast strains from different microorganism collections based on its antagonistic activity and gas production capacity.

The purpose of the research was to investigate the impact of $S$. cerevisiae yeast microorganisms on development of bacteria causing rope in bread, following the steps listed below:

- define antagonistic effect of S. cerevisiae on bacteria causing rope in bread using a solid nutrient medium, and then by putting test baked bread under provocative conditions;

- determine the effect of S. cerevisiae on the formation of carbon dioxide in the dough, the dough-making duration and the quality of the final products.

Control samples were prepared using S. cerevisiae RCAM 02150 yeasts widely used in the baking industry.

The antagonistic activity of yeast was detected by the method of diffusion to meat-peptone agar, Bacillus subtilis KM and B. licheniformis 1 were used as a testing culture. It is determined that culture liquid supernatant of the strain $S$. cerevisiae RCAM 01730 inhibits the growth of bacteria of the genera Bacillus in the lunulas. On the other hand, culture liquid supernatant of the strain S. cerevisiae RCAM intensifies bacterial growth. It allows to formulate an assumption about the presence of antagonistic activity of S. cerevisiae RCAM 01730 against bacteria of the genera Bacillus. This strain could be used for preventing of rope spoilage of bread during storage.

The main yeasts processing behavior is gas-production property resulting from enzyme activity. The maltase and zymase activities, dough fermentation property and osmo sensitivity have been determined. The tested yeasts have the higher zymase and maltase activities and dough fermentation property than the control sample by $17 \%, 15 \%$ and $25 \%$ correspondingly.

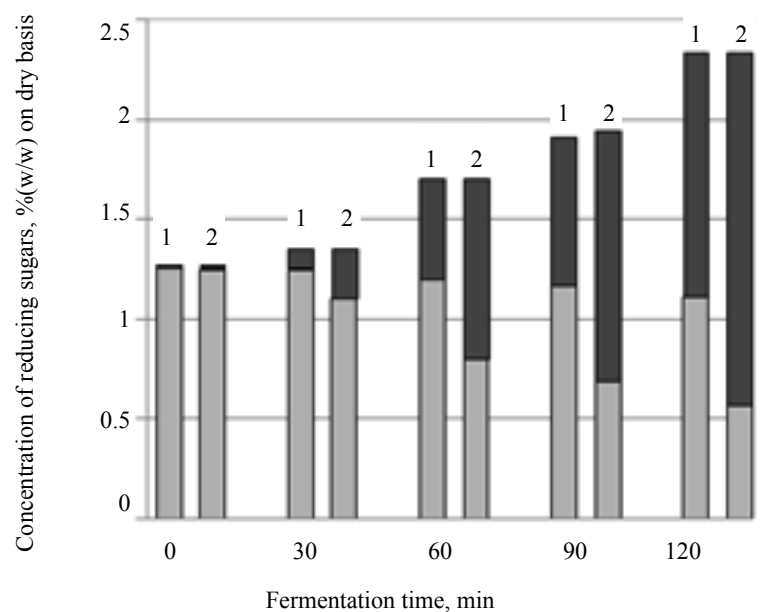

$\square$ - Residual amount

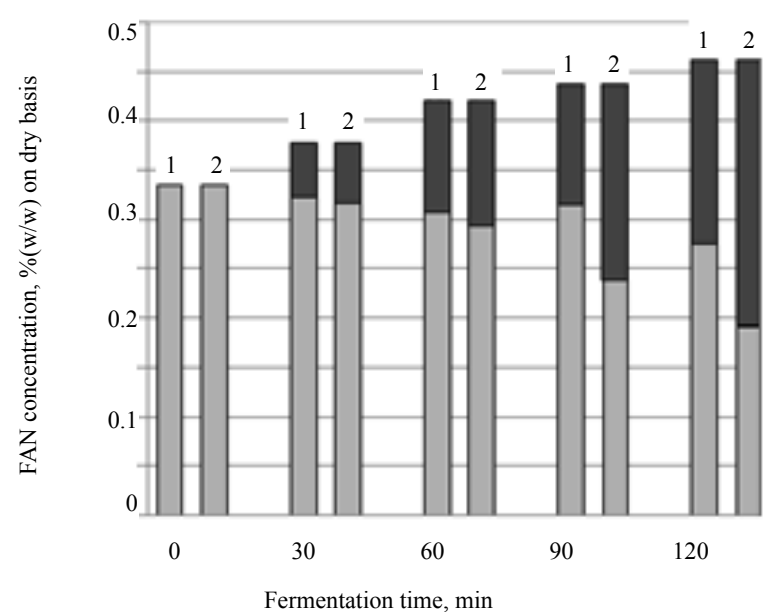

- Consumed amount

$b$

Figure 1. Changes in the content of reducing sugars (a) and FAN (b) in the dough with S. cerevisiae RCAM 02150 (1) and $S$. cerevisiae RCAM 01730 (2) 
Yeasts fermentation activity influenced on dough maturation time and finished product quality has been estimated by total volume of released gas, the instant gas-production, amount of residual sugars and free $\alpha$-amine nitrogen FAN in the dough.

The carbon dioxide production intensity was determined in dough samples prepared with the using of yeasts in dosages $1.0 \%, 2.5 \%$ and $4.0 \%$, which correspond to sponge and dough method, straight dough bulk fermentation and rapid processing. Yeasts strain S. cerevisiae RCAM 01730 (dosage $4.0 \%$ ) increase volume of carbon dioxide by $15 \%$ during 120 min of fermentation, then $2.5 \%$ during 180 min gives more by $18 \%, 1.0 \%$ during 240 min- more by $21 \%$ in comparison with yeasts $S$. cerevisiae RCAM 02150 shown.

Due to the action of amylolytic enzymes the reduction of sugars and FAN utilization by microorganisms occurs during the fermentation.

Studying changes in the content of reducing sugars and the FAN during the dough fermentation (Fig. 1), showed samples prepared with the yeast $S$. cerevisiae RCAM 01730, had intensive decrease of reducing sugars and FAN. In two hours of fermentation, with RCAM 01730 number of fermented sugars was more than $21 \%$, and consumed FAN $17 \%$ compared with the control.

Thus, the results of the study showed that the yeast strain S. cerevisiae RCAM 01730 are not inferior to strain RCAM 02150 in respect of biotechnological properties, therefore, these yeasts can be used for bread-production.

The influence of yeasts strain S. cerevisiae RCAM 01730 on the maturation time, the characteristics of pre fermented products under different technologies, the total time of doughmaking and the bread quality has been estimated. The dough was prepared from baker's top-grade wheat flour by rapid processing, straight dough fermentation and sponge and dough method (big tight and liquid sponges were used) with such dosages of yeasts as $4.0 \%, 2.5 \%$ and $1.0 \%$ correspondingly.
The dough prepared with yeasts $S$. cerevisiae RCAM 02150 was used as a control.

Experimental yeast allows to reduce dough fermentation and proofing the dough pieces (Table 1).

For example, by using the yeast $S$. cerevisiae RCAM 01730 , the total duration of the dough development reduced by $8 \%, 10 \%, 14 \%$ and $22 \%$ by sponge and dough method (big tight and liquid sponges), straight dough fermentation and rapid methods respectively in comparison with using the yeast $S$. cerevisiae RCAM 02150 . Thus, bread made by using strains of the yeast $S$. cerevisiae RCAM 01730 is not inferior to the control physical and chemical parameters (Table 1).

The sensory analysis (Fig. 2) showed that experimental samples have developed a thin wall porosity and have a more pronounced pleasant smell and taste.

It is determined that the use of yeast $S$. cerevisiae RCAM 01730 inhibits appearance of signs rope in bread.

Test laboratory baking of wheat bread with these yeast were made. The dough was prepared by sponge dough method, straight dough method and quick dough method with the yeast dosage yeast respectively 1.0, 2.5 and 4.0\%. Bread was stored in provoking conditions - temperature $37 \pm 1^{\circ} \mathrm{C}$ and relative humidity of $90 \%$. The appearance of signs rope in bread were estimated organoleptically (Table 2).

According to the research results it is possible to conclude that the strain $S$. cerevisiae RCAM 01730 has the antagonistic activity against the bacteria $B$. subtilis, B. licheniformis.

\section{Conclusions}

During our research we have ascertained that yeast strain S. cerevisiae RCAM 01730 has a bacteriostatic influence on causative agencies of rope in bread. Usage of the strain $S$. cerevisiae RCAM 01730 instead of S. cerevisiae RCAM 02150 accelerates gas production in dough, intensifies process of dough maturation and improves organoleptic properties of bread quality.

Effect of strains of the yeast $S$. cerevisiae to process parameters, quality parameters of semi-finished and final products

Table 1

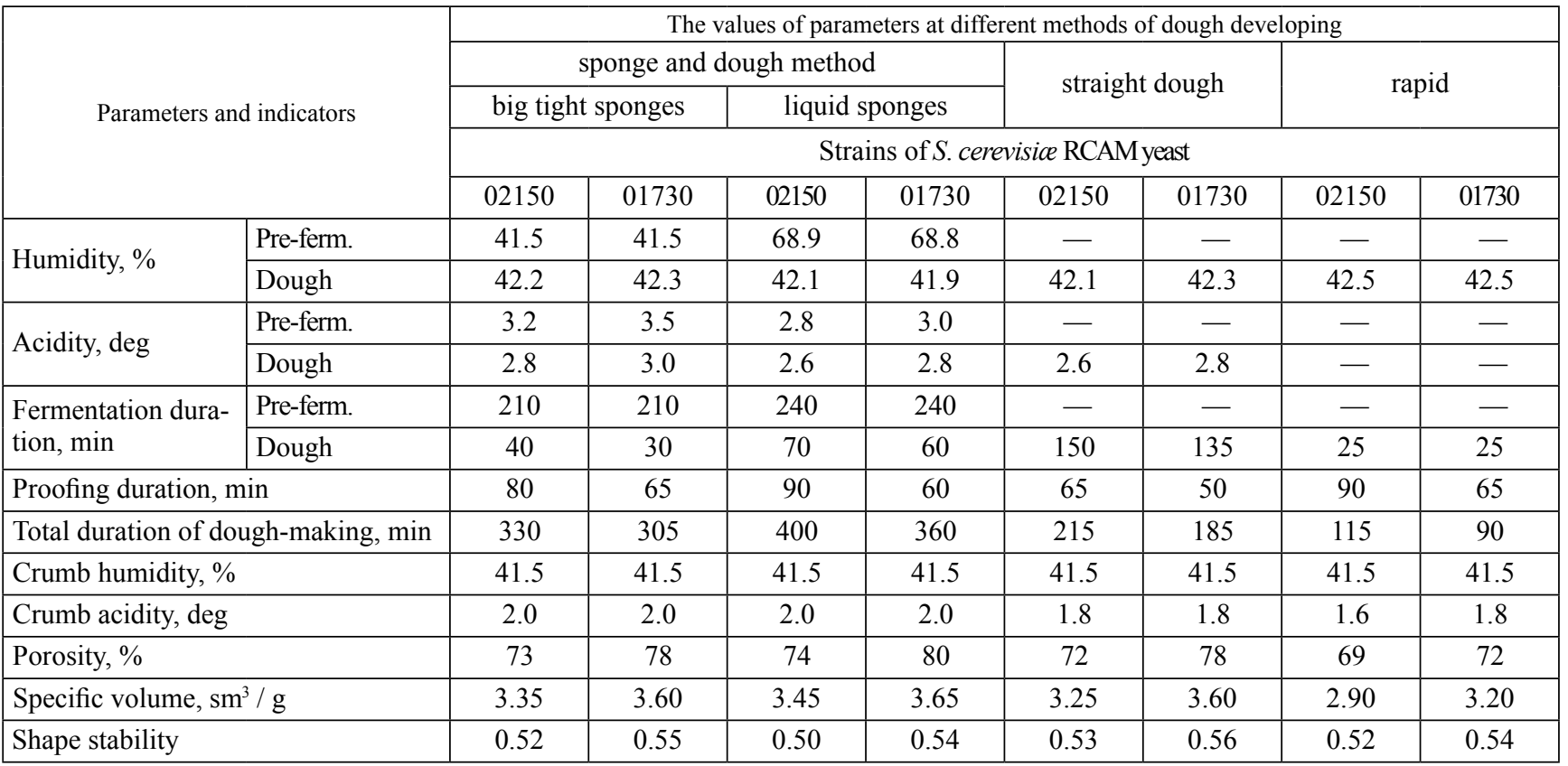




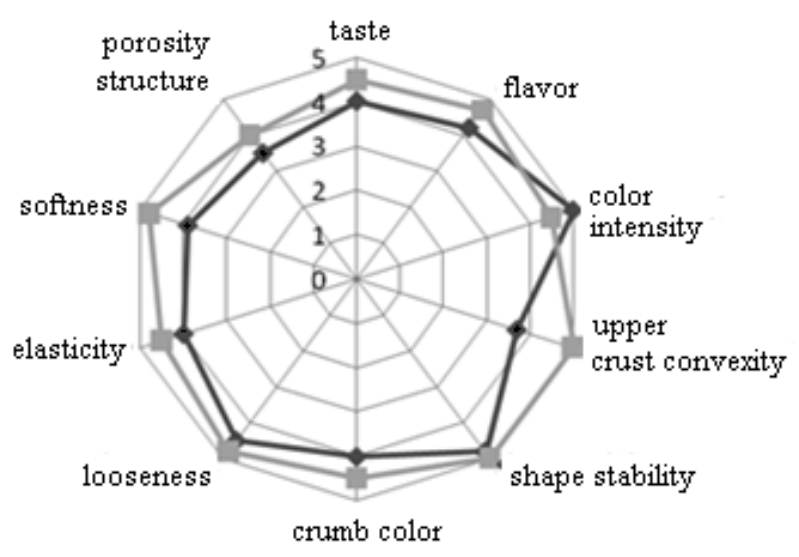

$\multimap$ RCAM $02150-$ RCAM 01730

Figure 2. Organoleptic quality indicators of bread made by straight dough method using different yeast strains

\section{References}

1. Fangio, M. F., Roura, S. I., \& Fritz, R. 2010. Isolation and identification of Bacillus spp. and related genera from different starchy foods. Journal of food science. 75 M218-M221.

2. Ybar, A., Cetinkaya, F., \& Soyutemiz, G. E. 2012. Detection of rope-producing Bacillus in bread and identificatio of isolates to species level by Vitek 2 System. Journal of Biological and Environmental Sciences. 6 (18), 243-248.

3. Sorokulova, I. B., Reva, O. N., Smirnov, V. V., Pinchuk, I. V., Lapa, S. V., \& Urdaci, M. C. 2003. Genetic diversity and involvement in bread spoilage of Bacillus strains isolated from flour and ropy bread. Letters in applied microbiology. 37 (2), 169-173.

4. Пучкова Л. И., Поландова Р. Д., Матвеева И. В. Технология хлеба, кондитерских и макаронных изделий. Часть 1. Спб.: Гиорд, 2005, c. 309 [Puchkova, L. I.; Polandova, R. D.; Matveeva, I. The technology of bread, pastry and pasta, vol. 1. GIORD Publishing House, St Petersburg, 2005. 309 pp. (in Russian)].

5. Von Holy, A. \& Allan, C. 1990. Current perspectives on rope in bread. In Smith, M. F., Kort, M. J., Clarke, I. R. and Bush, P. B.: Proceedings of the Second National Bakery Symposiumed. Technikon Natal Printers, Durban, pp. 119-125.

6. Voysey, P. A. 1989. Rope: a problem for bakers. J. Appl. Bacteriol. 67, xxv-xxvi.

7. Blackburn, C. (Ed.). 2006. Food spoilage microorganisms. Woodhead Publishing, 736 pp.

8. Cauvain, S. P., \& Young, L. S. (Eds.) 2007. Technology of breadmaking. Springer, New York, 420 pp.

9. Brandt, M. \& Spicher, Gottfried. 2006. Handbuch sauerteig: biologie, biochemie, technologie. Behr, Stuttgart-Feuerbach, 428pp.

10. Hatoum R, Labrie S. and Fliss I. 2012 Antimicrobial and probiotic properties of yeasts: from fundamental to novel applications. Front. Microbio. 3:421. doi: 10.3389 / fmicb. 2012.00421.

11. Casas, I. A., \& Dobrogosz, W. J. 2000. Validation of the probiotic concept: Lactobacillus reuteri confers broad-spectrum protection against disease in humans and animals. Microbial ecology in health and disease. 12 (4), 247-285.
Influence of yeast strains on development of microbiological spoilage during the bread storage

\begin{tabular}{|c|c|c|c|c|c|c|}
\hline \multirow{4}{*}{$\begin{array}{c}\text { Duration of } \\
\text { storage, hours }\end{array}$} & $\begin{array}{c}\text { Sponge dough } \\
\text { method }\end{array}$ & \multicolumn{7}{|c|}{$\begin{array}{c}\text { straight dough } \\
\text { method }\end{array}$} & \multicolumn{2}{c|}{$\begin{array}{c}\text { rapid dough } \\
\text { method }\end{array}$} \\
\cline { 2 - 7 } & \multicolumn{7}{|c|}{ Saccharomyces cerevisiae RCAM } \\
\cline { 2 - 7 } & $\begin{array}{c}\text { Strain } \\
02150\end{array}$ & $\begin{array}{c}\text { Strain } \\
01730\end{array}$ & $\begin{array}{c}\text { Strain } \\
02150\end{array}$ & $\begin{array}{c}\text { Strain } \\
01730\end{array}$ & $\begin{array}{c}\text { Strain } \\
02150\end{array}$ & $\begin{array}{c}\text { Strain } \\
01730\end{array}$ \\
\hline \multicolumn{7}{|c|}{ Development of rope in bread } \\
\hline 24 & - & - & + & - & + & - \\
\hline 48 & + & - & ++ & + & ++ & + \\
\hline 72 & ++ & + & ++ & ++ & ++ & + \\
\hline 96 & +++ & ++ & +++ & ++ & +++ & ++ \\
\hline
\end{tabular}

“_”_ no signs of microbiological spoilage;

"+" - initial signs of microbiological spoilage;

"++" — middle state of microbiological spoilage;

“+++" - intense microbiological spoilage

12. Gänzle, M. G., Höltzel, A., Walter, J., Jung, G., \& Hammes, W. P. 2000. Characterization of Reutericyclin Produced by Lactobacillus reuteri LTH2584. Applied and Environmental Microbiology, 66 (10), 4325-4333.

13. Ouwehandand A. C., Vesterlund, S. 2004. Antimicrobial Components from Lactic Acid Bacteria in Lactic Acid Bacteria Microbiological and Functional Aspects, Third Edition. Editors Seppo Salminen, Atte von Wright, and Arthur Ouwehand, CRC Press, USA, http://dx.doi.org / 10.1201 / 9780824752033.ch11

14. Talarico, T. L., \& Dobrogosz, W. J. 1989. Chemical characterization of an antimicrobial substance produced by Lactobacillus reuteri. Antimicrobial agents and chemotherapy. 33 (5), 674-679. doi:10.1128 / aac.33.5.674.

15. Hayduck,F. 1909. Uber einen Hefengiftstoff in Hefe. Wochenschr. Brau. 26, 677-679.

16. Golubev, W. I. 2006. Antagonistic interactions among yeasts. Biodiversity and Ecophysiology of Yeasts. Editors G. Péter and C. Rosa, Springer, p. 197-219.

17. Suzuki, C., Ando, Y., \& Machida, S. 2001. Interaction of SMKT, a killer toxin produced by Pichia farinosa, with the yeast cell membranes. Yeast, 18 (16), 1471-1478.

18. Прист Ф. Дж. Микробиология пива / под ред. Кэмпбелл Й. / пер. с англ. под общ. ред. Т. В. Мелединой и Тыну Сойдла. СПб: Профессия, 2005. [Priest,F. G. 2005. Brewing Microbiol$o g y$ / F. Priest, I. Campbell; translation from English under the editorship of Meledina, T. V.,Soidla N. Professiya, St. Petersburg, 368 pp. (in Russian).]

19. Salkinoja-Salonen, M. S., Vuorio, R., Andersson, M. A., Kämpfer, P., Andersson, M. C., Honkanen-Buzalski, T., \& Scoging, A. C. 1999. Toxigenic strains of Bacillus licheniformis related to food poisoning. Applied and environmental microbiology. 65 (10), 4637-4645.

20. Pepe, O., Blaiotta, G., Moschetti, G., Greco, T., \& Villani, F. 2003. Rope-producing strains of Bacillus spp. from wheat bread and strategy for their control by lactic acid bacteria. Applied and environmental microbiology. 69 (4), 2321-2329.

21. Rattin, G. E., Faubion, J. M., Walker, C. E., \& Mense, A. L. 2009. Measuring yeast $\mathrm{CO}_{2}$ production with the risograph. $\mathrm{Ce}$ real foods world. 54 (6), 261-265. 